\title{
Impact Assessment of Climate Change on Paddy Yield: A Case Study of Nepal Agriculture Research Council (NARC), Tarahara, Nepal
}

\author{
Yam K. Rai ${ }^{{ }^{*}}$, Bhakta B. Ale ${ }^{1}$, Jawed Alam ${ }^{2}$ \\ ${ }^{1}$ Department of Mechanical Engineering, Pulchowk Campus, IOE \\ ${ }^{2}$ Department of Agricultural Engineering, Purwanchal Campus, IOE
}

\begin{abstract}
Climate change and global warming are burning issues, which significantly threat agriculture and global food security. Change in solar radiation, temperature and precipitation will influence the change in crop yields and hence economy of agriculture. It is possible to understand the phenomenon of climate change on crop production and to develop adaptation strategies for sustainability in food production, using a suitable crop simulation model. CERES-Rice model of DSSAT v4.0 was used to simulate the rice yield of the region under climate change scenarios using the historical weather data at Nepal Agriculture Research Council (NARC) Tarahara (1989-2008). The Crop Model was calibrated using the experimental crop data, climate data and soil data for two years (2000-2001) and was validated by using the data of the year 2002 at NARC Tarahara. In this study various scenarios were undertaken to analyze the rice yield. The change in values of weather parameters due to climate change and its effects on the rice yield were studied. It was observed that increase in maximum temperature up to $2^{\circ} \mathrm{C}$ and $1^{\circ} \mathrm{C}$ in minimum temperature have positive impact on rice yield but beyond that temperature it was observed negative impact in both cases of paddy production in ambient temperature. Similarly, it was observed that increased in mean temperature, have negative impacts on rice yield. The impact of solar radiation in rice yield was observed positive during the time of study period. Adjustments were made in the fertilizer rate, plant density per square meter, planting date and application of water rate to investigate suitable agronomic options for adaptation under the future climate change scenarios. Highest yield was obtained when the water application was increased up to $3 \mathrm{~mm}$ depth and nitrogen application rate was $140 \mathrm{~kg} / \mathrm{ha}$ respectively.
\end{abstract}

Keywords: Climate change, DSSAT v4.0, CERES-Rice, rice yield.

\section{Introduction}

Rice is the second most important crop in the world after wheat and also the most important crop in Nepal. It is grown on about 145 million hectares in the world with annual production of 518 million tones of rice (FAO, 2004). In Nepal, rice is the main food for $65 \%$ of the total population and contributes $50.24 \%$ of total food grain production (CBS, 2007). Rice crop is adapted to a greater range of climatic conditions than any other single cereal species. As such, cultivated lands range from lowlands, floodplains, and deltas to forested hills and mountains. Rice grows best in the areas which have supply of water for perennial flooding of the soil up to $5 \mathrm{~cm}$ deep.

Food security in South Asia today is threatened by yield stagnation, and possible decline in future rice yields, in the face of continuing population growth. The current threats to sustainability of rice production are overexploitation of ground and surface waters, water logging and salinity, declining soil organic matter, water and atmospheric pollution, and global climate change. Rice production is affected by sets of various and environmental parameters, including genetic 
characteristics of crop, soil properties, weather conditions and cultivation management. Rice grain yield for a given cultivar is mainly dependent upon local climatic conditions such as solar radiation and temperature, when plants are grown on the conditions of ample nutrients and water.

Rice cultivated area of Nepal is $1,439,525$ hectare and national average rice production rate is $2.55 \mathrm{Ton} / \mathrm{ha}$ (CBS, 2007). The yield of rice in Nepal varies between 0 to $3 \mathrm{Ton} / \mathrm{ha}$ at the subdistrict level. In Jhapa, Morang, Sunsari, Bara and Parsa the yield of rice is greater than 3 Ton/ha, but in Manang and Mustang the yield of rice is 0 Ton/ha. Region wise production of rice was found to be 2.64 Ton/ha, 2.67 Ton/ha, 2.34 Ton/ha, 2.67 Ton/ha and 2.64 Ton/ha in eastern Terai, central Terai, western Terai, mid-western Terai and far western Terai respectively. The main reasons for the low rice yields are inadequate cultivation practices, poor management, and insufficient fertilizer application. Rain fed rice is grown under poor conditions, i.e. poor crop management with low inputs and is subjected to climatic variability. Therefore, generally yield is low in most part of the country and also yield gaps are high. The major production constraints are high rainfall variability, drought, submergence and inherent low soil fertility.

Poor management in rice cultivation is one of the factors for low yield, besides that appropriate rice cultivar selection for local climatic condition is another challenge for the farmers, therefore we need a tool, so that we can overcome such types of problems. A DSSAT (Decision Support System for Agrotechnology Transfer) model is such a tool which is used for simulating crop growth parameters and adaptation options. The model was developed under the International Benchmark Sites Network for Agrotechnology Transfer (IBSNAT) project. DSSAT is integrated software of different computer programs, which can facilitate the application of crop simulation models in research and decision-making. It has much more flexible functionality for database manipulation and model application than any other existing crop growth simulation models. It enables the user to match the biological requirements of crops to the physical characteristics of land so that objectives specified by the user, may be satisfied.

In this case study, the local climatic conditions, crop data and soil data were undertaken of Nepal Agriculture Research Council (NARC), Tarahara and DSSAT models (CERES Rice v 4.0) were used to simulate the rice yield in different scenarios and adjustments were made in different parameters to investigate suitable agronomic options for adaptation under the future climate change scenarios. The present study was conducted to asses the impact of climate change on paddy yield which will be helpful to the farmers, agronomist, scientist, decision makers and planners.

\section{Field layout and experimental details}

The experimental area was divided into 27 plots of $6 \mathrm{~m} \times 4 \mathrm{~m}$ size maintaining a buffer of $0.5 \mathrm{~m}$ between adjacent plots. The field experiments were designed as per randomized block design (RBD) with application of $\mathrm{N}, \mathrm{P}, \mathrm{K}$ and organic compost treatments as the factors. There were nine treatments and three replications. The local high yielding rice variety namely "Mansuli" (Mayang Ebos 80*2।Tichaung 65) was considered as the experimental crop in the study. 
Table 1: Detail of experimental layout

\begin{tabular}{|l|l|}
\hline Variety & Mansuli (Mayang Ebos 80*2\Tichaung 65) \\
\hline Design & RBD \\
\hline Replication & 3 \\
\hline Treatments & 9 \\
\hline Plot size & $6 * 4=24 \mathrm{~m}^{2}$ \\
\hline Harvested size (area) & $12 \mathrm{~m}^{2}$ \\
\hline Spacing & $20 * 20 \mathrm{~cm}(\mathrm{R} * \mathrm{P})$ \\
\hline Date of transplanting & 22 July, 2001 \\
\hline Top dressing & 30 November,2001 \\
\hline Plants per $\mathrm{m}^{2}$ & 215 \\
\hline Harvesting date & $30 \mathrm{November}, 2001$ \\
\hline & Yield Components \\
\hline Plant Height & $113.06 \mathrm{~cm}$ \\
\hline Yield & $3.510 \mathrm{Ton} / \mathrm{ha}$ \\
\hline Harvest Index & 0.28 \\
\hline Straw Weight & $9116.5 \mathrm{~kg} / \mathrm{ha}$ \\
\hline
\end{tabular}

Source: NARC, Tarahara, 2001

In this study, only the average values of soil properties and grain yields were under taken to simulate the crop yield in different scenarios.

\section{Methodology}

The data for the current study were obtained from the experimental research work carried out at the experimental farm of the Nepal Agriculture Research Council (NARC) Tarahara, Sunsari, Nepal (Latitude $26^{\circ}, 42^{\prime}$ and Longitude $87^{\circ}, 16^{\prime}$ ) during 2000-2001. The farm is situated at an altitude of $200 \mathrm{~m}$ above the mean sea level. The data was generated by NARC, Tarahara in long term fertility test in Mansuli (Mayang Ebos $80 * 21$ Taichung 65) variety of rice and rice wheat cropping system was used to analyze.

\section{Data collection and analysis}

In this study secondary data were used to assess the impact of climate change on grain yield of rice. Basically, crop production data and soil data were collected from NARC, Tarahara and weather data measured in Tarahara (weather station) from the Department of Hydrology and Metrology (1989-2008). CERES Rice v 4.0 models were used to analyze the rice grain yield in different scenarios. All the data were processed in the required form and entered in the CERES 
Rice v 4.0 models. Model was calibrated with measured crop data and crop genetic coefficient was determined and validation was made by using crop genetic coefficient. The experimental field was of rice wheat cropping system and, chemical fertilizer and compost fertilizer were applied in same quantity in both rice and wheat cropping. Soil was analyzed at the depth of 10 $\mathrm{cm}$ and $20 \mathrm{~cm}$ and result was found to be as shown below in Tables 2, 3 and 4 .

Table 2: Analysis of soil in NARC Tarahara

\begin{tabular}{|l|l|l|l|l|l|l|}
\hline $\begin{array}{l}\text { No. of } \\
\text { Treatments }\end{array}$ & NPK kg/ha & $\mathbf{p H}$ & $\mathbf{O M \%}$ & $\mathbf{N \%}$ & $\mathbf{P}_{\mathbf{2}} \mathbf{S}_{\mathbf{5}} \mathbf{~ k g} / \mathbf{h a}$ & $\mathbf{K O}_{\mathbf{2}} \mathbf{~ k g} / \mathbf{h}$ \\
\hline T1 & $00: 00: 00$ & 6.70 & 1.35 & 0.12 & 90.33 & 118.50 \\
\hline T2 & $100: 00: 00$ & 6.53 & 1.03 & 0.10 & 104.30 & 185.00 \\
\hline T3 & $100: 40: 00$ & 6.70 & 1.18 & 0.08 & 153.20 & 131.50 \\
\hline T4 & $100: 00: 30$ & 6.23 & 1.33 & 0.10 & 98.03 & 143.68 \\
\hline T5 & $100: 40: 30$ & 6.37 & 1.40 & 0.09 & 125.87 & 120.17 \\
\hline T6 & $100: 00: 00$ & 7.00 & 1.29 & 0.08 & 116.13 & 135.67 \\
\hline T7 & $50: 00: 00$ & 5.93 & 1.42 & 0.09 & 100.80 & 157.30 \\
\hline T8 & $50: 20: 00$ & 6.37 & 1.29 & 0.34 & 112.70 & 148.57 \\
\hline T9 & FYM@ 10 T/ha & 6.53 & 1.50 & 0.11 & 112.07 & 139.64 \\
\hline Average & & 6.49 & 1.31 & 0.13 & 112.6 & 142.22 \\
\hline
\end{tabular}

Table 3: Physical and chemical properties of soil found in experimental field at Tarahara. (Chaudhary, 1999)

\begin{tabular}{|c|c|c|c|c|c|c|c|c|c|}
\hline \multirow{2}{*}{$\begin{array}{c}\text { Soil } \\
\text { depth } \\
\text { (cm) }\end{array}$} & \multicolumn{3}{|c|}{$\begin{array}{c}\text { Particle size } \\
\text { distribution (\%) }\end{array}$} & \multirow{2}{*}{$\mathrm{pH}$} & \multirow{2}{*}{$\begin{array}{c}\text { Soil } \\
\text { organic } \\
\text { carbon } \\
(\%)\end{array}$} & \multirow{2}{*}{$\begin{array}{c}\text { Bulk } \\
\text { density } \\
\left(\mathrm{g} / \mathrm{cm}^{3}\right)\end{array}$} & \multirow{2}{*}{$\begin{array}{c}\text { Total } \\
\mathrm{N} \\
(\%)\end{array}$} & \multirow{2}{*}{$\begin{array}{c}\text { Total } \\
\mathrm{P} \\
(\%)\end{array}$} & \multirow{2}{*}{$\begin{array}{c}\text { Total } \\
\mathrm{K} \\
(\%)\end{array}$} \\
\hline & Clay & Silt & Sand & & & & & & \\
\hline $0-10$ & 12.73 & 29.61 & 50.40 & 6.90 & 1.02 & 10 & 0.1 & - & - \\
\hline $10-20$ & 10.48 & 33.34 & 55.45 & 6.49 & 1.31 & 1.15 & 0.09 & - & - \\
\hline
\end{tabular}


Table 4: Experimental crop data of NARC Tarahara

\begin{tabular}{|c|c|c|c|c|c|}
\hline Treatments & $\begin{array}{c}\text { Plant height } \\
(\mathrm{cm})\end{array}$ & $\begin{array}{c}\text { Panicle height } \\
(\mathrm{cm})\end{array}$ & $\begin{array}{c}\text { Grain weight } \\
(\mathrm{kg} / \mathrm{plot})\end{array}$ & $\begin{array}{c}\text { Straw weight } \\
(\mathrm{kg} / \mathrm{plot})\end{array}$ & $\begin{array}{c}\text { Yield } \\
(\mathrm{Ton} / \mathrm{ha})\end{array}$ \\
\hline $\mathrm{T} 1$ & 104.77 & 21.07 & 3.80 & 7.33 & 3.17 \\
\hline T2 & 112.20 & 22.27 & 3.60 & 9.17 & 3.11 \\
\hline T3 & 118.07 & 22.27 & 4.47 & 13.00 & 3.72 \\
\hline T4 & 112.33 & 21.87 & 4.20 & 12.00 & 3.50 \\
\hline T5 & 119.80 & 22.40 & 4.30 & 12.33 & 3.58 \\
\hline T6 & 110.47 & 21.07 & 4.23 & 12.17 & 3.53 \\
\hline T7 & 111.20 & 22.27 & 4.17 & 9.17 & 3.47 \\
\hline T8 & 108.93 & 21.93 & 3.80 & 9.17 & 3.17 \\
\hline T9 & 119.80 & 23.53 & 5.23 & 13.83 & 4.36 \\
\hline Average & 113.06 & 22.08 & 4.20 & 10.91 & 3.51 \\
\hline
\end{tabular}

\section{Trend analysis}

The Mann-Kendall non-parametric test was used to analyze the trend of variation in seasonal climatic parameters such as: solar radiation, maximum temperature, minimum temperature and rainfall. In this study 20 years of data (1989-2008) were analyzed by the Mann-Kendall nonparametric test.

The Mann-Kendall statistic (S) is given by,

$$
S=\sum_{k=1}^{n-1} \sum_{j=k+1}^{n} \operatorname{sign}\left(x_{j}-x_{k}\right)
$$

Variance of S, VAR(S) is calculated by the following equation,

$$
\operatorname{VAR}(S)=\frac{1}{18}\left[n(n-1)(2 n+5)-\sum_{p=1}^{g} t_{p}\left(t_{p}-1\right)\left(2 t_{p}+5\right)\right]
$$

Normalized test statistic $(Z)$ is calculated as follows,

$$
\begin{aligned}
& Z=\frac{S-1}{[\operatorname{VAR}(S)]^{1 / 2}} \text { if }(S>0) \\
& Z=0 \text { if }(S=0) \\
& Z=\frac{S+1}{[\operatorname{VAR}(S)]^{1 / 2}} \text { if }(S<0)
\end{aligned}
$$

The probability associated with this normalized test statistic is calculated as follows, 


$$
F(z)=\frac{1}{\sqrt{2 \Pi}} e\left(-\frac{z^{2}}{2}\right)
$$

\section{Sensitivity Analysis}

The sensitivity analysis was performed with crucial parameters including P1, P2R, P5, P2O, G1 and initial dry matter content. The relative sensitivity of various parameters were calculated by changing each parameter by $5 \%$ and keeping other parameters constant.

$$
\text { Re lativeSensitivity }=\frac{(A-B) * 100(\%)}{B} X \frac{1}{C(\%)}
$$

Where,

$$
\begin{aligned}
& \text { A - grain yield for changed parameter } \\
& \text { B - original grain yield } \\
& \text { C - relative change in parameter, } \%
\end{aligned}
$$

\section{Simulating the impact of temperature and $\mathrm{CO}_{2}$}

Simulation of the duration of each physiological stage uses the concept of thermal time (Ritchie et al., 1998). Because the time scale of plants are closely coupled with its thermal environment, thinking of thermal time as a plant's view of time is appropriate. Thermal time has units of ${ }^{\circ} \mathrm{C}$ day. The simplest and most useful definition of thermal time $t_{d}$ is

$$
t_{d}=\sum_{i=1}^{n}\left(T_{a}-T_{b}\right)
$$

Where, $T_{a}$ is daily mean air temperature, $T_{b}$ is the base temperature at which development stops and $\mathrm{n}$ is the number of days of temperature observations used in the simulation. The calculation of $\mathrm{T}_{\mathrm{a}}$ is accomplished in the CERES models by averaging the daily maximum and minimum temperatures under most circumstances. In case of rice the value of $\mathrm{T}_{b}$ is $9^{\circ} \mathrm{C}$.

\section{Solar radiation calculation $(\mathrm{Rs})$}

The daily sunshine hours were used to calculate the solar radiations by using the Angstrom formulae given as follows:

$$
\operatorname{Rs}=(0.285+0.392 \mathrm{n} / \mathrm{N})
$$

Where,

$$
\begin{aligned}
& \text { Rs - solar radiation }\left(\mathrm{MJm}^{-2} \mathrm{day}^{-1}\right) \\
& \mathrm{n} \text { - actual duration of sunshine (hour) } \\
& \mathrm{N} \text { - maximum possible duration of sunshine }
\end{aligned}
$$


$\mathrm{n} / \mathrm{N}$ - relative sunshine duration

$\mathrm{Ra}$ - extra terrestrial radiation $\left(\mathrm{MJm}^{-2} \mathrm{day}^{-1}\right)$

\section{Results and discussions}

The results of this case study on impact of climate change on yield of rice crop, using the crop growth simulation model with different climate change scenarios were presented and discussed in this section. The meteorological elements governing growth, development, production, and quality of rice at a given site were basically air temperatures, solar radiation, photoperiod, soil moisture, and crop water use or evapotranspiration. Knowledge of climatic requirements of rice and its physiological responses to the environment is extremely important to help growers to produce high yields under site-specific atmospheric conditions. Crop growth models can be used to provide estimates of rice yield as a function of climatic factors at a particular locality. The CERES-Rice model, for instance, takes into consideration daily data on temperature, photoperiod, solar radiation, soil water and nitrogen supply.

\section{Analysis of trend}

Trend of variation in climatic data was analyzed using the Mann-Kendall method, which is a non parametric test for identifying trends in time series data. The test compares the relative magnitude of sample data rather than the data values by themselves. Solar radiation, maximum temperature, minimum temperature and rainfall during the crop growth period (June to Mid November) at NARC Tarahara (1989-2008), were analyzed to check their trend. The data values were evaluated as an order time series and each data value was compared with all subsequent data values. All weather parameters were analyzed of seasonal (planting to harvesting period) data. Solar radiation, minimum temperature, rainfall were found to be no trend. But maximum temperature was found to be the increasing trend as seen in Table 5 .

Table 5: Mann-Kendall trend results for solar radiation, maximum temperature and minimum temperature and rainfall at NARC Tarahara

\begin{tabular}{|l|c|c|c|l|}
\hline Weather Parameter & $\begin{array}{c}\text { Mann- } \\
\text { Kendall } \\
\text { statistic (S) }\end{array}$ & $\begin{array}{c}\text { Normalized } \\
\text { test statistic } \\
(\mathbf{Z})\end{array}$ & Probability & Trend* \\
\hline Tarahara & 7 & 0.36 & 0.64 & No Trend \\
\hline Solar radiation & 85 & 2.72 & 0.99 & Increasing Trend \\
\hline Maximum temperature & 1 & 0.00 & 0.50 & No Trend \\
\hline Minimum temperature & 12 & 0.35 & 0.64 & No Trend \\
\hline Rainfall & & & & \\
\hline
\end{tabular}

* At $5 \%$ level of significance 


\section{Model calibration}

For calibration of model the experimental data were collected from research stations NARC Tarahara along with soil and daily weather data were used as the input parameter and the results obtained from the model were compared with the observed values. The percentage error is within the range of $\pm 5 \%$ which is considered satisfactory for the model calibration. The comparison of observed and simulated values is presented below in the Table 6 and there was not much significant difference in the observed and simulated values. The observed and simulated grain yields were as shown in Table 6. The percentage error obtained from the experiment on grain yield was $1.56 \%$. Genetic coefficients were determined (Table 7) by adjusting trial and error methods to bring the simulated grain yield near to the observed grain yield.

Table 6: Observed and simulated yield components for the experiment at NARC, Tarahara for variety of Mansuli 2001

\begin{tabular}{|l|l|l|l|l|l|}
\hline S.N & \multicolumn{4}{|l|}{ Grain Yield (Ton/ha) } & \\
\hline & Simulated & Observed & $\mathrm{Si}-\mathrm{Ob}$ & $\%$ error & $\begin{array}{l}\text { Yield after genetic } \\
\text { coefficient adjusted }\end{array}$ \\
\hline 1 & 3.565 & 3.510 & 0.055 & $1.56 \%$ & $3.515(\mathrm{Ton} / \mathrm{ha})$ \\
\hline
\end{tabular}

Table 7: Genetic coefficients for the rice cultivars Mayang Ebos 80*2\Taichung 65

\begin{tabular}{|c|c|c|c|c|c|c|c|c|}
\hline Genetic coefficient $\longrightarrow$ & \multirow{2}{*}{ P1 } & \multirow{2}{*}{ P5 } & \multirow{2}{*}{$\mathrm{P} 2 \mathrm{R}$} & \multirow{2}{*}{$\mathrm{P} 2 \mathrm{O}$} & \multirow{2}{*}{ G1 } & \multirow{2}{*}{ G2 } & \multirow{2}{*}{ G3 } & \multirow{2}{*}{ G4 } \\
\hline Rice cultivar & & & & & & & & \\
\hline $\begin{array}{l}\text { Mayang Ebos } \\
80 * 2 \backslash \text { Taichung } 65\end{array}$ & 502.3 & 500.0 & 168.0 & 11.2 & 54.0 & 0.028 & 1.0 & 1.0 \\
\hline
\end{tabular}

The genetic coefficients used for growth and developments of rice varieties are defined as follows:

P1: Basic vegetative phase, it is the time period expressed as growing degree days [GDD] in ${ }^{\circ} \mathrm{C}$ above a base temperature of $9^{\circ} \mathrm{C}$.

P2O: Critical photoperiod or the longest day length in hours at which the development occurs at a maximum rate.

P2R: Photoperiod sensitivity coefficient, extent to which the phase development leading to panicle initiation is delayed.

P5: Time period in GDD ${ }^{\circ} \mathrm{C}$ from beginning of grain filling to physiological maturity with a base temperature of $9^{\circ} \mathrm{C}$ 
G1: Potential spikelet number per panicle

G2: Single grain weight (g)

G3: Tillering coefficients

G4: Temperature tolerance coefficient

\section{Validation of CERES-Rice model}

The model was calibrated using two years of field experimental data of 2000 and 2001 . Then the model was validated using the crop data of the year 2002. The genetic coefficients were determined by the process of calibration.

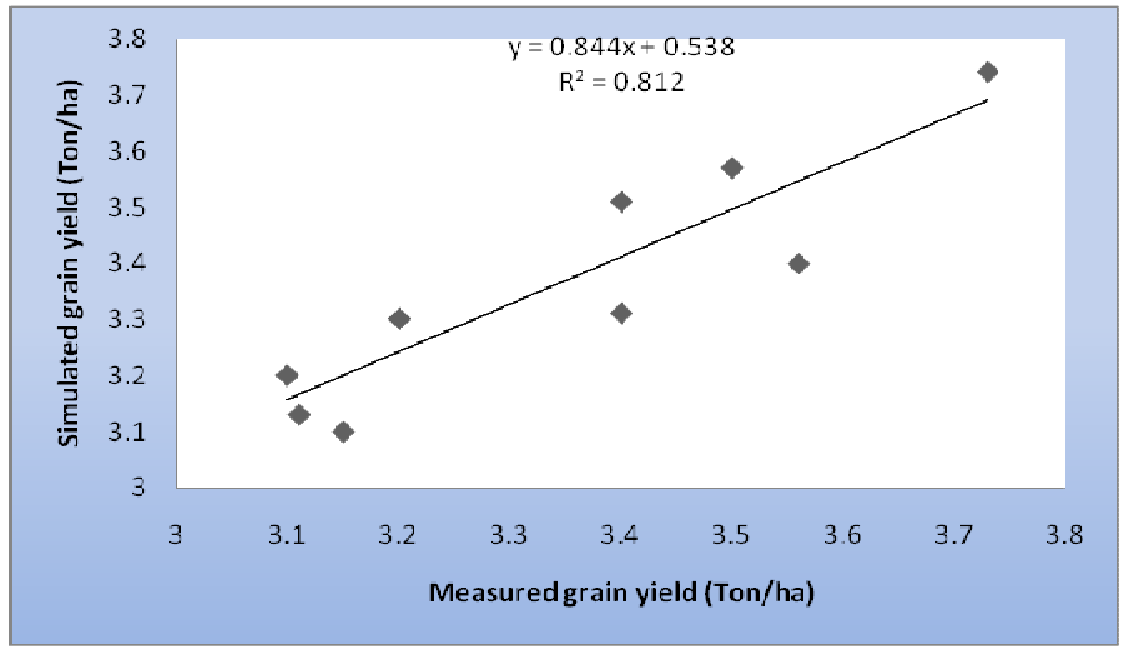

Fig. 1: Comparison of measured and simulated grain yield of rice during the years 2000-2002.

The measured and simulated grain yield for three years (2000-2002) revealed that the simulated grain yield matched well with the corresponding measured values for any experiment. Comparison of the simulated and measured grain yield at harvested period for three years is presented in Fig. 1. A reasonably good agreement was found between simulated and measured values of grain yield during all experiments. The regression analysis gave a coefficient of determination $\left(\mathrm{R}^{2}\right)$ value of 0.812 .

\section{Effect of temperature on growth and yield of rice}

Temperature regime greatly influences not only the growth duration but also the growth pattern of the rice plant. During the growing season, the mean temperature, and the maximum and minimum temperature, rainfall distribution pattern, and diurnal changes, or a combination of these, may be highly correlated with grain yields (Moomaw and Vergara, 1965). 
Table 8: Effect of temperature on growth and yield of rice

\begin{tabular}{|l|c|c|c|}
\hline \multirow{2}{*}{ Growth Stage } & \multicolumn{3}{|c|}{ Critical temperature $\left({ }^{\circ} \mathbf{C}\right)$} \\
\cline { 2 - 4 } & Low & High & Optimum \\
\hline Germination & $16-19$ & 45 & $18-40$ \\
\hline Seedling emergence and establishment & $12-35$ & 35 & $25-30$ \\
\hline Rooting & 16 & 35 & $25-28$ \\
\hline Leaf elongation & $7-12$ & 45 & 31 \\
\hline Tillering & $9-16$ & 33 & $25-31$ \\
\hline
\end{tabular}

Sterility caused by cool night temperatures (below $15^{\circ} \mathrm{C}$ ) $10-14$ days before heading (Rutger and Peterson 1979).

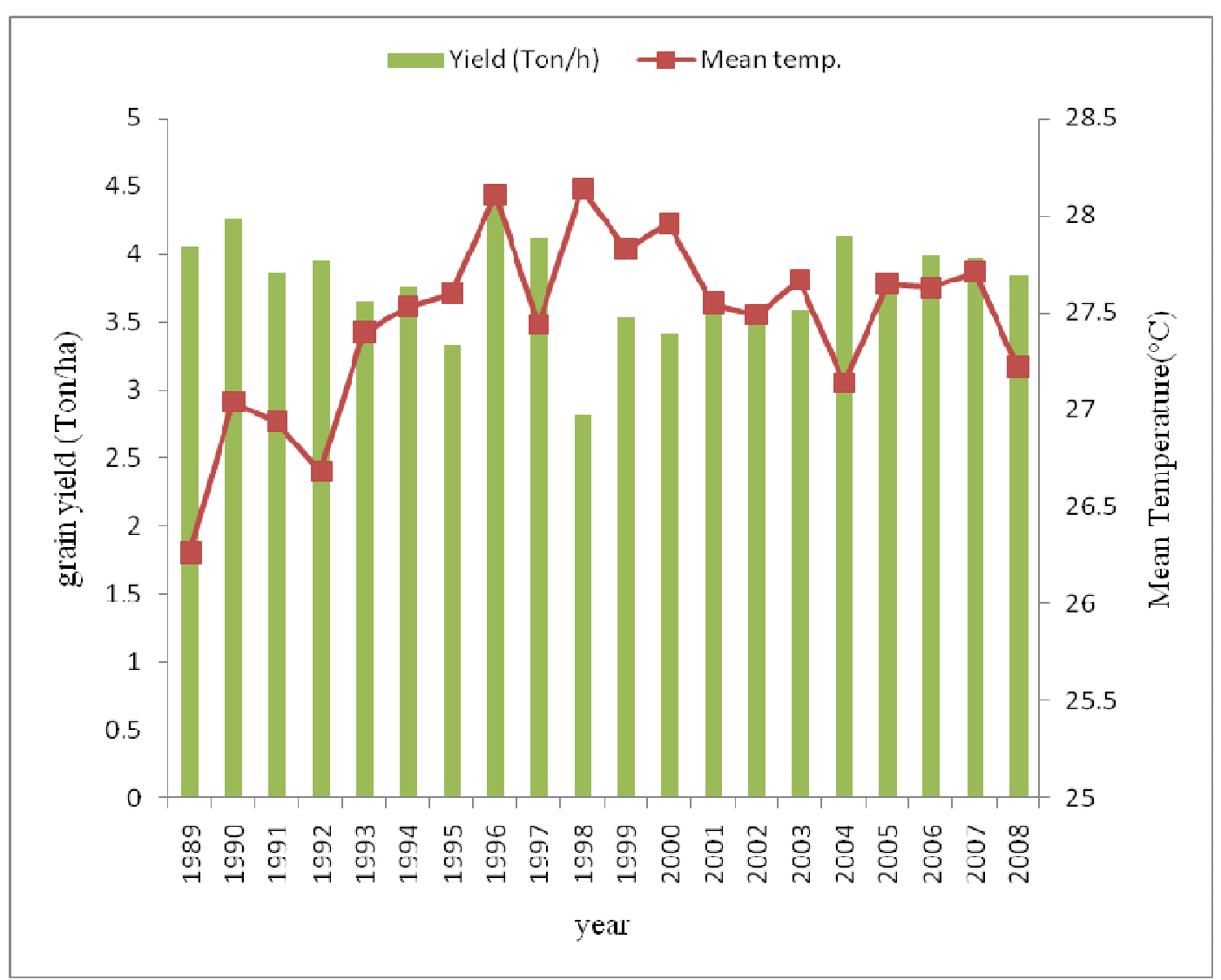

Fig. 2: Variation in rice yield with mean temperature at NARC Tarahara years (1989-2008)

The calibrated CERES-rice model was used to simulate the rice yield at NARC, Tarahara, and the simulated rice yield was compared with observed mean temperature, maximum and minimum temperature during the growing period of the crop. As shown in Fig. 2 rising mean temperature leaded to decrease in rice yield as revealed during the years 1993, 1994, 1995, 1998, 1999, 2000 respectively for NARC Tarahara. It is also observed from Fig. 4, the lower mean temperature 
exerted positive impact on the rice yields. Yield and mean temperature response curves (Fig. 3) showed that there was a decreasing trend in grain yield of rice per degree rise in seasonal mean temperature.

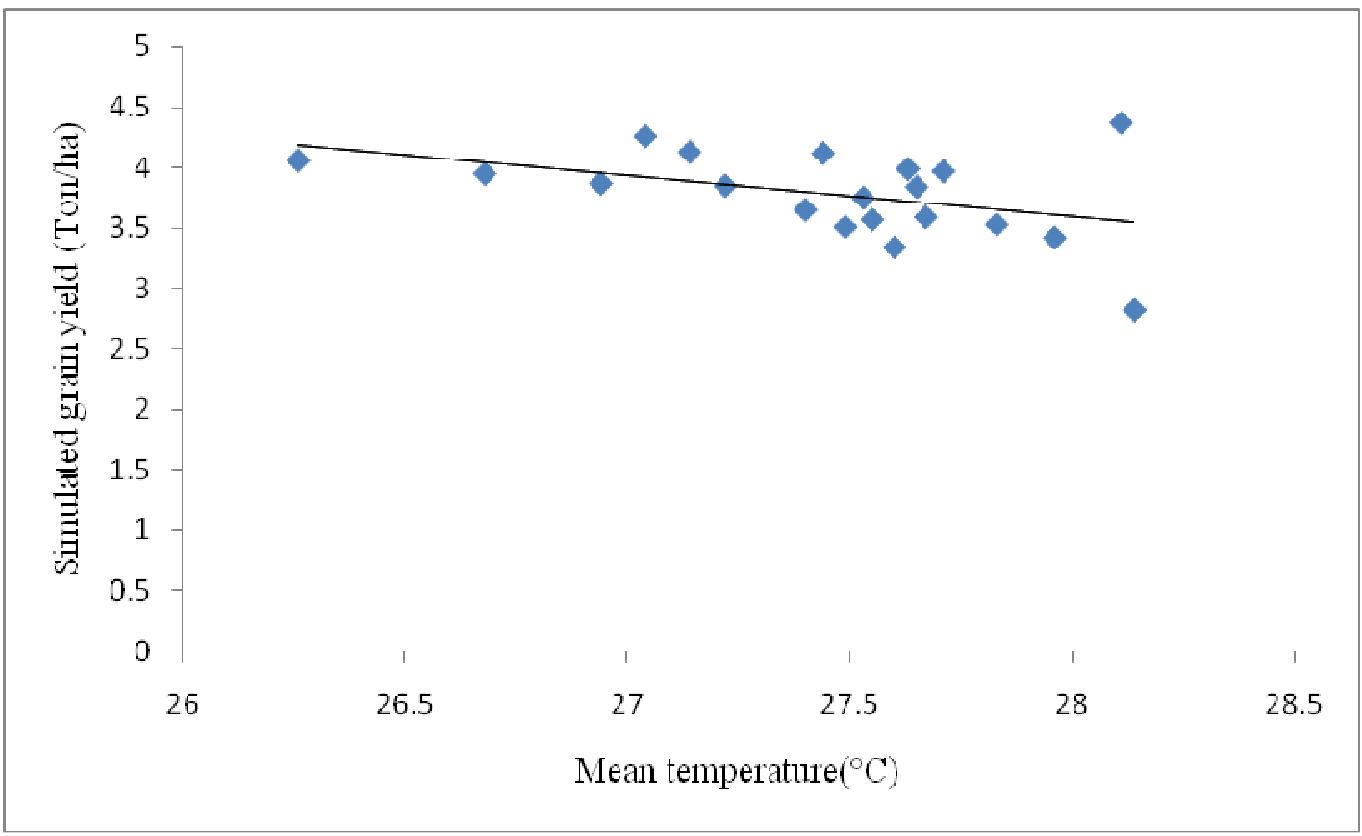

Fig. 3: Relation between mean temperature and rice yield at NARC, Tarahara

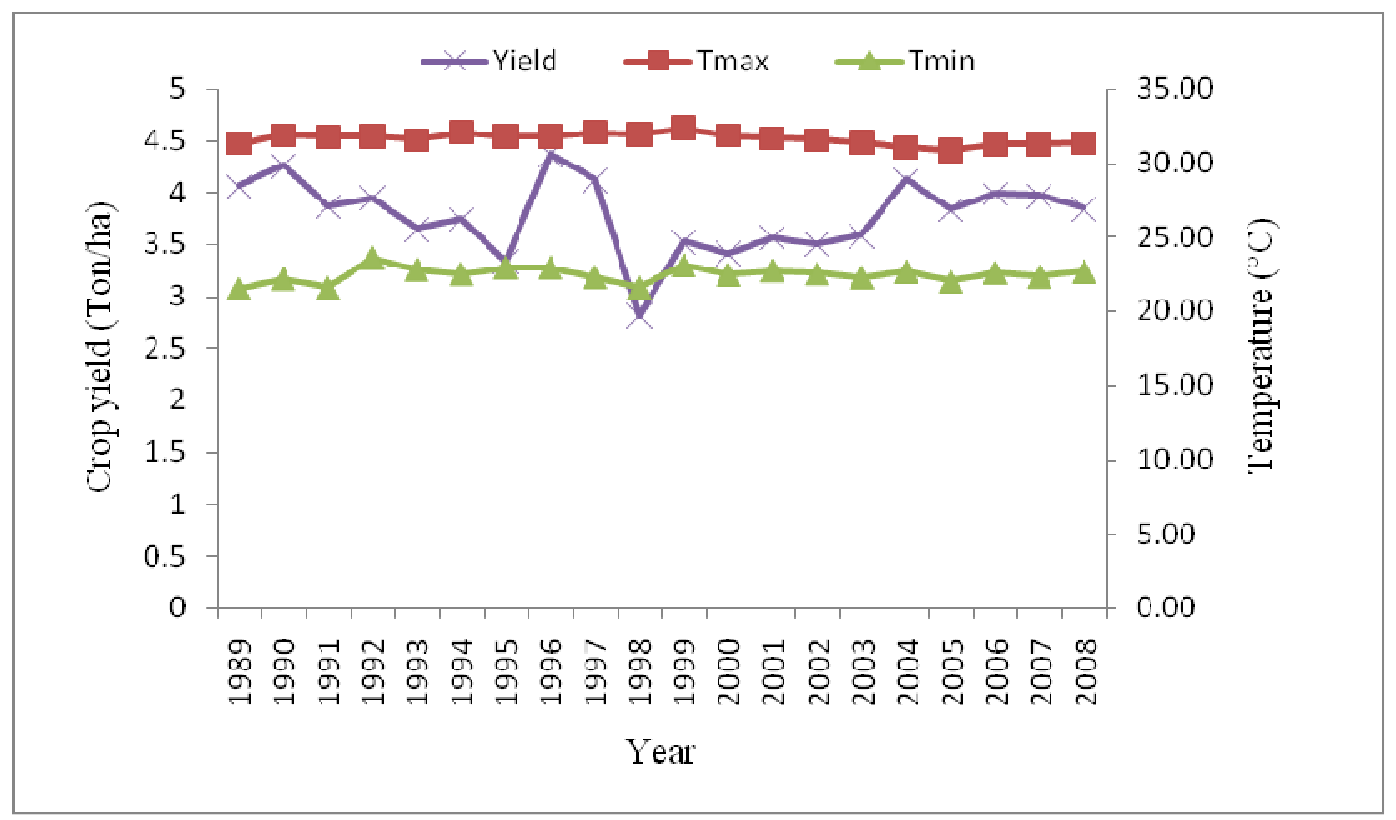

Fig. 4: Variation in rice yield with maximum and minimum temperatures at NARC, Tarahara during the years 1989-2008 
A negative yield response to diurnal temperature range (DTR; the difference between daily maximum and minimum temperature), coupled with a negative yield response to average temperature in most regions, indicated that temperature increase is more harmful during day than at night. It was common to have maximum daily temperatures from $35^{\circ}-41^{\circ} \mathrm{C}$ or higher in semiarid regions and during hot months in tropical Asia. In these areas, a heat- susceptible variety may suffer from a high percentage of sterility induced by high temperature. Spikelet sterility from high temperature is induced largely on the day of flowering. Within the flowering day, high temperature during anthesis was the most detrimental to spikelet fertility, high temperature just before anthesis was the second most detrimental and high temperature after anthesis had little effect on spikelet fertility.

Low temperature at night reduces the expansion of leaves. As a result, less photosynthesis occurs and specific leaf weight increases and thereby the proportion of assimilate partitioned to the roots increases. It is important to try to capture the effects of temperature sequences during critical vernalization and growth periods while simulating climate change impact. In general, higher temperatures during the growing season will be associated with higher radiation and a demand for more water, which along with elevated $\mathrm{CO}_{2}$ concentration are major factors that have to be considered in any impact assessment.

From Fig. 4, it was clear that the rising maximum temperature had a negative impact on the rice yield at NARC, Tarahara as can be seen in the years 1995, 1998, 1999 and 2000. Lower temperature prolongs the growth duration of rice and reduces the crop growth rate. The rice grows well where the night temperature does not go below $18^{\circ} \mathrm{C}$. In this study, the minimum temperature never dropped below $19^{\circ} \mathrm{C}$ during the growing season of rice (Fig. 4). But the rice yield was simulated in maximum, minimum and in mean temperature by adding 1,2,3, 4, and $5^{\circ} \mathrm{C}$ in existing temperature and the corresponding simulated yield was obtained as shown below in the Table 9.

Table 9: Effect of plus temperature in max., min. and mean existing temperature

\begin{tabular}{|c|c|c|c|}
\hline $\begin{array}{c}\text { Temperature } \\
\left({ }^{\circ} \mathbf{C}\right)\end{array}$ & $\begin{array}{c}\text { Yield at Max. Temp. } \\
\text { (Ton/ha) }\end{array}$ & $\begin{array}{c}\text { Yield at Min. Temp. } \\
\text { (Ton/ha) }\end{array}$ & $\begin{array}{c}\text { Yield at Mean Temp. } \\
\text { (Ton/ha) }\end{array}$ \\
\hline+1 & 3.67 & 3.56 & 3.42 \\
\hline+2 & 3.55 & 3.34 & 3.13 \\
\hline+3 & 3.35 & 3.27 & 3.12 \\
\hline+4 & 3.22 & 3.26 & 2.68 \\
\hline+5 & 3.2 & - & 1.88 \\
\hline
\end{tabular}

Increment in same amount of temperature in minimum temperature was found very harmful than compared to the maximum temperature for rice yield (Table 9). 
In this case study impact of increasing trend in both cases maximum and minimum temperature were found to have negative impact in rice yield, but impact of increasing trend only either in maximum temperature or in minimum temperature was observed to have positive impact in rice yield (Table 9). In trend analysis, all parameters were found no trend except maximum temperature. But, studied (analyze by CERES rice model) showed that increment in solar radiation and rainfall had positive impact in rice yield (Figs. 6 and 10).

\section{Effect of temperature and $\mathrm{CO}_{2}$ levels at fixed increments on rice yield}

Carbon dioxide is considered a greenhouse gas due to its high absorptance in several wavelengths of the thermal infrared radiation emitted by earth's surface. The greater the content of gases in the atmosphere that absorb thermal infrared radiation emitted from the earth surface, the greater the thermal infrared radiation emitted by the atmosphere towards the earth surface. Consequently, the long wave balance of the surface will be less negative and more energy will be available for latent and sensible heat fluxes at the earth's surface. As more energy is available for sensible heat flux air temperature is expected to rise.

If the increase in atmospheric $\mathrm{CO}_{2}$ concentration is accompanied by an increase in air temperature, crops may shorten their growth cycle, which may offset the advantages of an increasing $\mathrm{CO}_{2}$ concentration. Therefore, the interacting effects of $\mathrm{CO}_{2}$ concentration and temperature on plant growth are complicated. $\mathrm{CO}_{2}$ is a component of plant photosynthesis and therefore influences biomass production. It also regulates the opening of plant stomata and therefore affects plant transpiration. As a result, plants growing in increased $\mathrm{CO}_{2}$ conditions will produce more biomass and will consume less water.

Table 10: Crop yield variation under incremental temperature and $\mathrm{CO}_{2}$ concentration during the year 2001 at NARC, Tarahara

\begin{tabular}{|c|c|c|c|c|c|c|}
\hline \multicolumn{7}{|c|}{ Crop yield (Ton/ha) } \\
\hline \multirow{2}{*}{$\begin{array}{c}\mathrm{CO}_{2} \\
\text { Concentrations } \\
(\mathbf{p p m})\end{array}$} & \multicolumn{6}{|c|}{ Temperature increments $\left({ }^{\circ} \mathrm{C}\right)$} \\
\hline & $\mathbf{0}$ & +1 & +2 & +3 & +4 & +5 \\
\hline 330 & 3.51 & 3.43 & 3.15 & 3.13 & 2.70 & 2.03 \\
\hline 430 & 3.36 & 3.54 & 3.40 & 3.17 & 2.75 & 2.11 \\
\hline 480 & 3.30 & 3.37 & 3.52 & 3.25 & 2.75 & 2.21 \\
\hline 530 & 3.36 & 3.30 & 3.60 & 3.40 & 2.70 & 2.32 \\
\hline 580 & 3.38 & 3.61 & 3.69 & 3.56 & 2.78 & 2.47 \\
\hline 630 & 3.79 & 3.91 & 3.65 & 3.66 & 2.87 & 2.47 \\
\hline
\end{tabular}

The potential yield of rice was simulated at NARC, Tarahara, using the crop growth model under the combinations of $\mathrm{CO}_{2}$ and temperature with fixed increments in $\mathrm{CO}_{2}$ concentrations $(330,430$, $480,530,580$ and $630 \mathrm{ppm}$ ) and temperatures (ambient, $+1,+2,+3,+4,+5^{\circ} \mathrm{C}$ ) individually and 
with all combinations of $\mathrm{CO}_{2}$ and temperature for the year 2001. At all the $\mathrm{CO}_{2}$ levels tested, the simulated rice yield decreased due to an increase in temperature except increment made by $+1^{\circ}$ C. On the other hand for an increase in $\mathrm{CO}_{2}$ level at any particular temperature, rice yields were found to be increased as given in Table 10 .

Simulated yields showed that increased $\mathrm{CO}_{2}$ concentrations increased the crop yield. For each degree of temperature increment doubling of $\mathrm{CO}_{2}$ produced the highest yield. At the current level (2001) of $\mathrm{CO}_{2}$ concentration (considered as 330ppm), model predicted 3.43, 3.15, 3.13, 2.70 and $2.03 \mathrm{Ton} / \mathrm{ha}$ grain yield for $+1,+2,+3,+4$, and $+5^{\circ} \mathrm{C}$ increase in temperature respectively. But increasing $\mathrm{CO}_{2}$ concentration up to $630 \mathrm{ppm}$ the crop yield was simulated as $3.79 \mathrm{Ton} / \mathrm{ha}$ (Table 10). However, with $+4^{\circ} \mathrm{C}$ temperature increase above ambient temperature, the crop yield did not increased remarkably as shown in Fig. 5. If a physiological limit exists for the fixation and transport of carbon, increasing photoperiod and light intensity under high $\mathrm{CO}_{2}$ enrichment may not maximize rice yield. The net assimilation rate and canopy net photosynthesis also increased with increasing $\mathrm{CO}_{2}$ concentration. The elevated $\mathrm{CO}_{2}$ concentration was found to accelerate the development but shorten the total growth period of rice crop. Two responses of crops to elevated $\mathrm{CO}_{2}$ are an increase in the rate of photosynthesis and a decrease in stomata conductance.

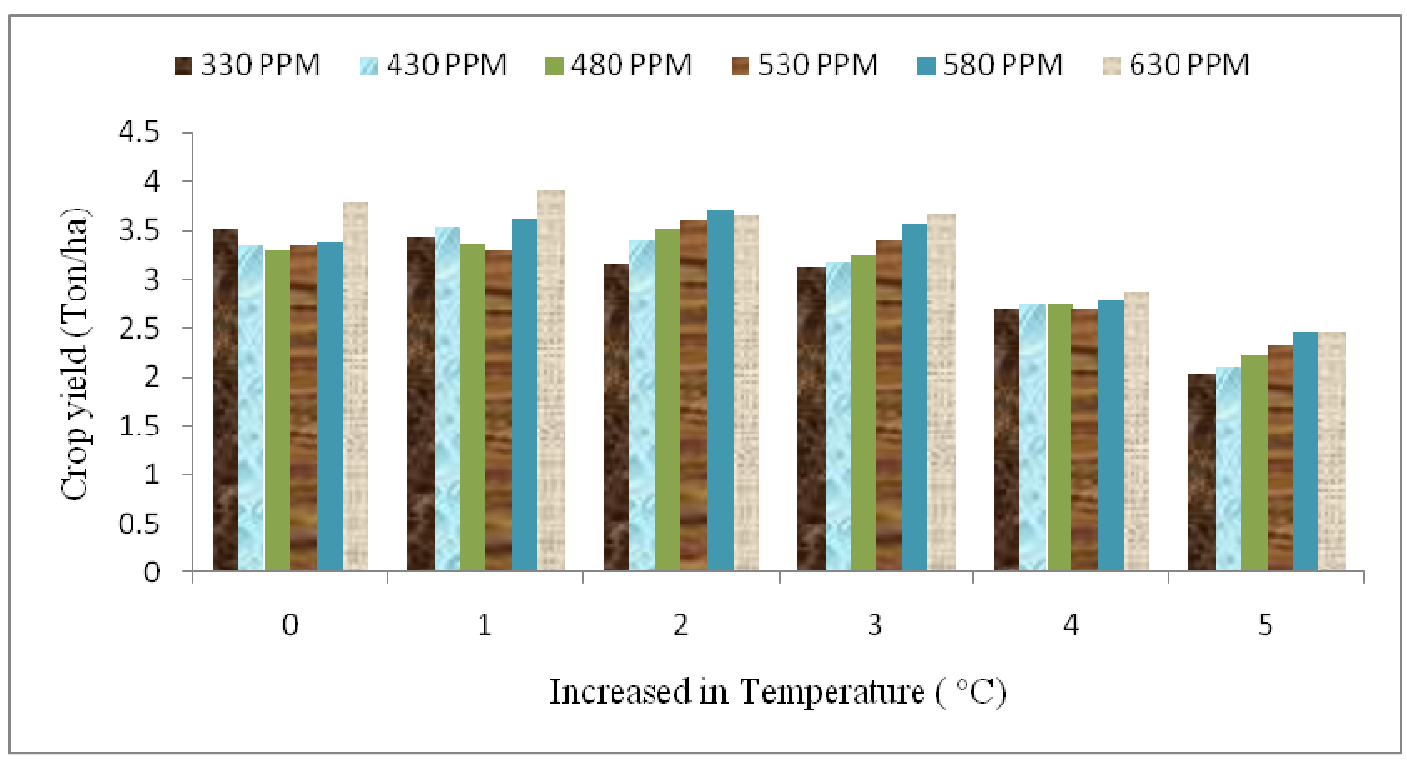

Fig. 5: Variation in simulated rice yield under incremental atmospheric $\mathrm{CO}_{2}$ concentrations and incremental temperatures during the year 2001

As simulated by the crop simulation model, an increase in temperature at any $\mathrm{CO}_{2}$ level considered would cause a decline in rice yields but an increase in $\mathrm{CO}_{2}$ level at each temperature increment would increase rice yields (Table 10 and Fig. 5). The reduction in grain weight by heat stress in cereals is attributed to the effect of temperature on the rate and duration of grain growth period.

\section{Effect of solar radiation on rice yield}

Intercepted solar radiation has a direct effect on biomass accumulation. In controlledenvironment growth cabinets where the irradiation is constant, high temperature reduced the 
duration of grain-filling, resulting in lower cumulative radiation receipt and lower grain-yield. For field-grown crops, high temperature is often associated with absence of rainfall and high evaporative demand. Therefore, the rainfed rice dependence on rainfall, in the tropics must grow in low sunlight intensity. On the other hand, where irrigation water is available, rice can be grown in the dry season and the grain yield will be higher than in the wet season because of the higher intensity of solar radiation.

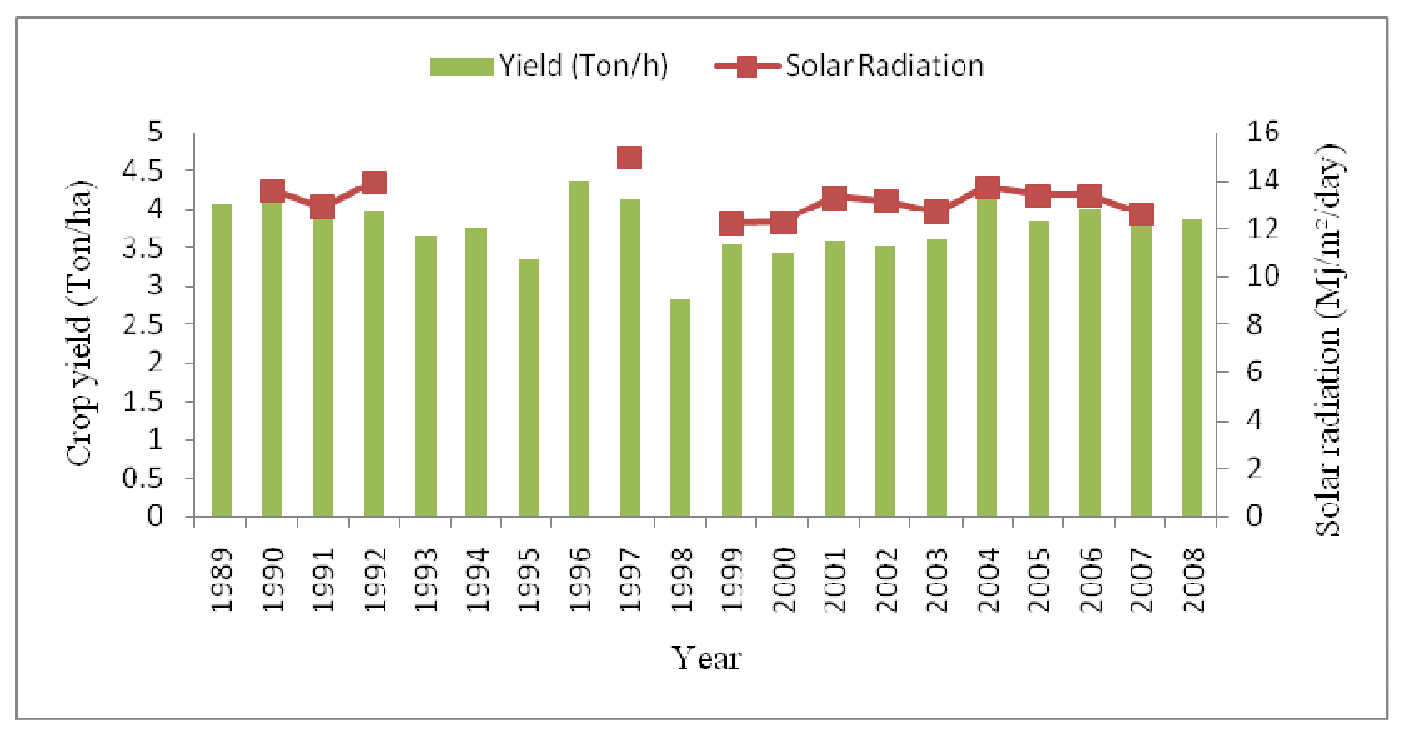

Fig. 6: Variation in crop yield with solar radiation at NARC, Tarahara during the years 1989-2008

Rice plant's most critical period of solar energy requirement is from panicle initiation until about 10 days before maturity. Earlier experiments indicated a strong correlation between grain yield and solar radiation during the last 30 days of crop growth. Subsequent IRRI research indicated that the increase in dry matter between panicle initiation and harvest was highly correlated with grain yield. In case of this case study, rice yield was found when solar radiation increased at NARC, Tarahara, crop yield was increased due to increase in dry matter between panicle initiation and harvesting periods.

\section{Evaluation of agro adaptation measures}

The various possible agro adaptation measures include alternate planting/sowing dates, water management, planting density, different tillage depths, nutrient management, improved heat resistant varieties, etc. Among these, alternate planting/sowing date, planting density and nutrient management were applied to the calibrated CERES-Rice model for NARC, Tarahara and the impact on the crop yield was assessed.

\section{Effect of change in planting date on rice yield}

Different studies have suggested that adjusting the planting dates and determining the optimum dates for planting will be helpful in reducing the effect of climate change. Adjustment of management practices may help to offset any detrimental effects of climate change on rice production. Probably the easiest adaptation strategy to cope with climate change is to adjust the 
planting/sowing dates. The selection of an earlier planting date for rice will probably be the appropriate response to offset the negative effect of a potential increase in temperature. This change in planting date will allow for the crop to develop during a period of the year with lower temperatures, thereby decreasing developmental rates and increasing the growth duration, especially the grain filling period. Adjustment of planting date and simulation of its effect was done using the model to investigate a suitable agronomic option for adaptation under the future climate change scenarios.

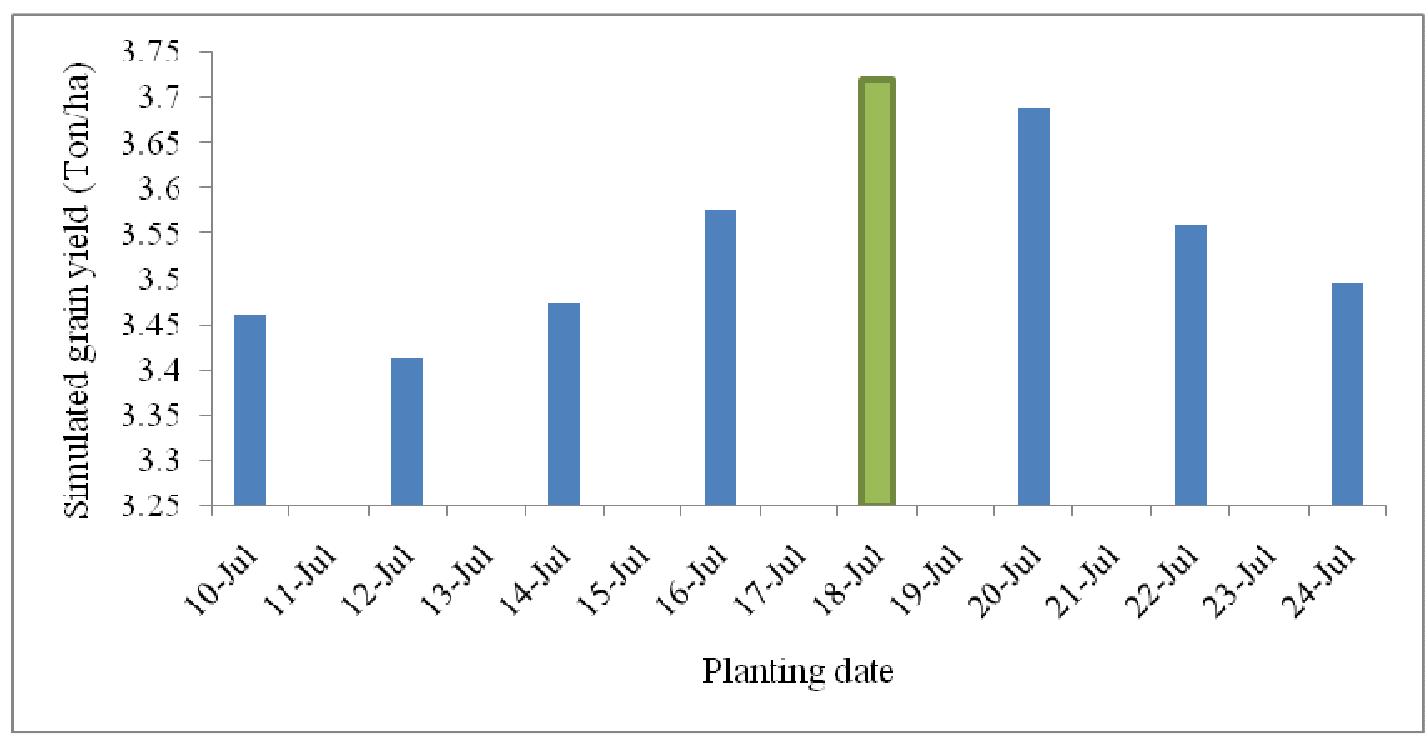

Fig. 7: Variation in rice yield with change in planting dates at NARC, Tarahara

The potential outcome of adjusting the planting dates at NARC, Tarahara was simulated using the CERES-rice model for the year 2001 to assess the effect of climate change, as shown in Fig. 7. To determine the optimum planting dates the potential outcomes were studied by shifting the planting dates 5 days before and 9 days after the actual date of planting $\left(22^{\text {th }} \mathrm{July}\right)$ at an interval of 2 days. The rice yield was simulated for each date and the changes in yield corresponding to the experimental yield for actual planting date was calculated. Among the different planting dates considered, the planting date of $18^{\text {th }}$ July, that is 4 days before the actual planting date was considered to be the most beneficial for NARC, Tarahara in terms of increase in yield. When the date of planting was shifted 4 days before with respect to actual date of planting, the rice yield was increased of $0.2 \mathrm{Ton} / \mathrm{ha}$. It should be noted, however, that although changes in planting date are a no-cost decision that can be taken at the farm-level, a large shift in planting dates probably would interfere with the agrotechnological management of other crops, grown during the remainder of the year.

\section{Effect of plant density on rice yield}

The yield of crop depends largely on temperature, solar radiation, moisture and soil fertility for their growth and nutritional requirement. Plant population density affects crop yield indirectly, through increase in the level of competition, i.e., the plant-to-plant interference with the equal sharing of growth resources increases almost linearly with the increase of plant density. 
Therefore, it is important to determine the optimum density of plant population per unit area for obtaining maximum grain yield.

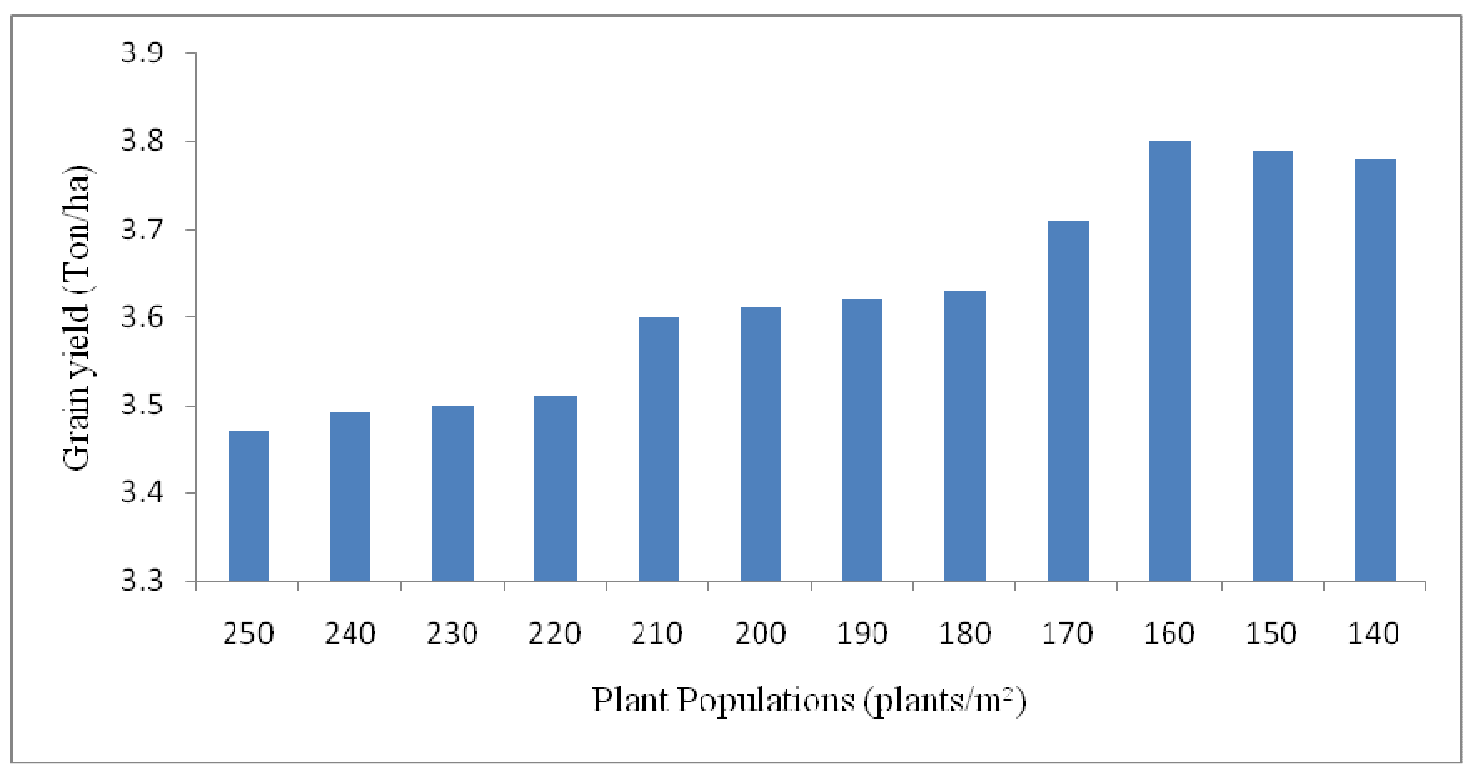

Fig. 8: Rice yield at various plant densities at NARC, Tarahara

The effect of change in plant density was studied in the range of 140 to 250 plants per $\mathrm{m}^{2}$ for coping with climate change scenario. It was observed that the plants density 160 plants $/ \mathrm{m}^{2}$ produced the highest yield at NARC, Tarahara (Fig. 8). The yield was found to decrease with increase as well as decrease in plant density as compared to plant density of 160 plants $/ \mathrm{m}^{2}$.

\section{Effect of different fertilizer rate on rice yield}

Nitrogen is one of the most important nutrients limiting the rice production. Inherently infertile soils coupled with the critical nutrient mining in farmers fields implies that external $\mathrm{N}$ fertilizer has to be applied if optimal crop yield is to be achieved. Under the heterogeneous soil conditions, site-specific nutrient management has to be used if under or over application in some areas of the farmer's fields is to be avoided. Soil type, soil fertility management and nitrogen fertilizer significantly affected the growth and ultimately the rice yield. The CERES-Rice model was used to evaluate the rice yield when different dozes of nitrogen were used at NARC, Tarahara. The highest yield was obtained at NARC, Tarahara (4.03 Ton/ha) with the application of $140 \mathrm{~kg} / \mathrm{ha}$ of nitrogen (Fig. 9). 


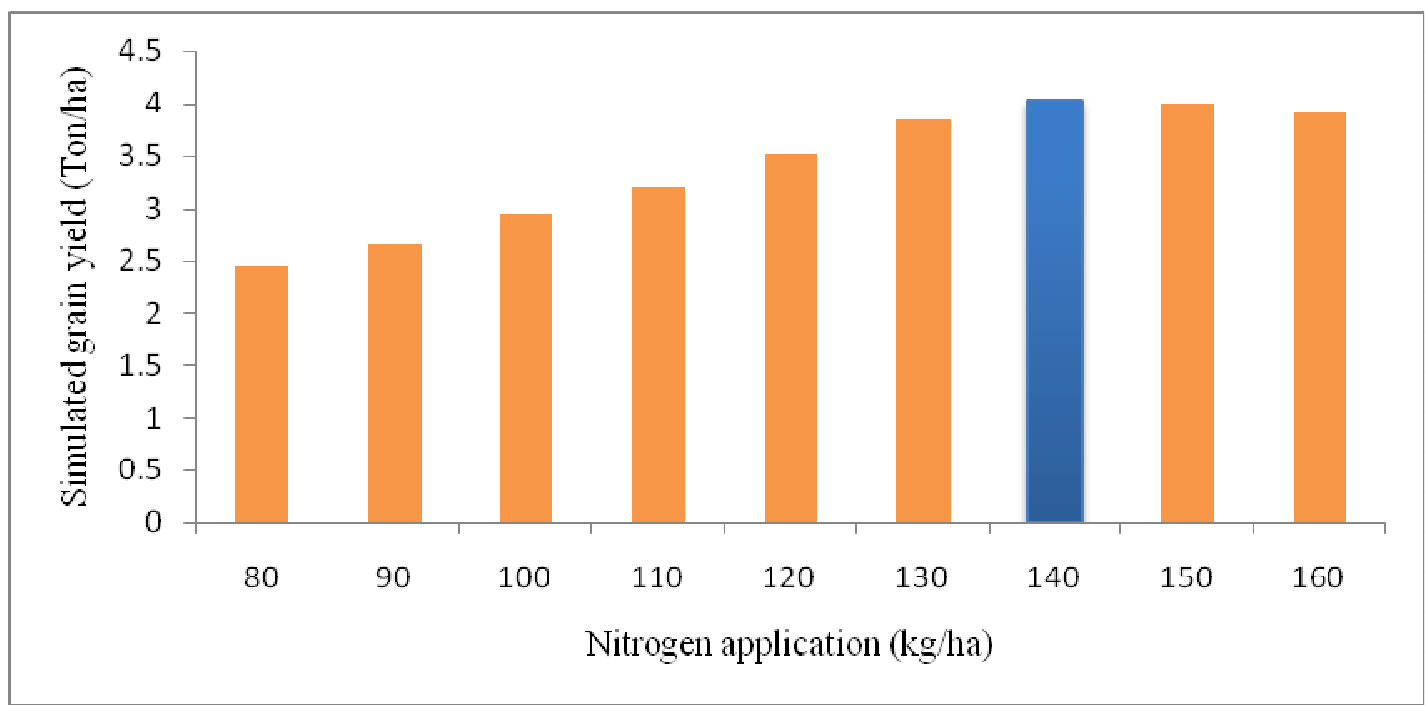

Fig. 9: Rice yield in response to nitrogen fertilizer application at NARC, Tarahara.

The CERES-Rice model was used to evaluate the effect of nitrogen application rate in Rice yield from $80-160 \mathrm{~kg} / \mathrm{ha}$ in $10 \mathrm{~kg} / \mathrm{ha}$ of interval. Maximum positive impact was found $0.52 \mathrm{Ton} / \mathrm{ha}$ when the nitrogen application rate was $140 \mathrm{~kg} / \mathrm{ha}$ with compare to actual application rate $(120 \mathrm{~kg} / \mathrm{ha})$ and maximum negative impact was found $1.07 \mathrm{Ton} / \mathrm{ha}$ when the nitrogen was applied $80 \mathrm{~kg} / \mathrm{ha}$.

\section{Effect of different irrigation rate on rice yield}

Agriculture is strongly dependent on water resources and climatic conditions. The evolution of rice as a food crop was influenced primarily by amount and distribution of rainfall.

June- September is the Monsoon season. Monsoon normally starts in the second week of June and reaches full development in July. Monsoon is the main source of precipitation, which enters the country from eastern part of Nepal. As the monsoon enters Nepal, topography plays an important role for the distribution of rainfall ranging from about $150 \mathrm{~mm}$ to over $5000 \mathrm{~mm}$ per annum. About $80 \%$ of the annual precipitation falls during this period. But, in case of Tarahara rainfall is around $1950 \mathrm{~mm}$ per annum. This should be adequate for one rice crop provided rainfall distribution is reasonably uniform. Even in areas where the annual rainfall is 1200-1500 $\mathrm{mm}$, if rainfall is concentrated in the monsoonal season (as is usual), it is adequate for a single rice crop.

In this case study application of water (irrigation+ rainfall) was sufficient or deficit was checked by adding water in environmental modification option with the help of CERES Rice models. Different depth ( $1 \mathrm{~mm}, 2 \mathrm{~mm}, 3 \mathrm{~mm}, 4 \mathrm{~mm}, 5 \mathrm{~mm}, 6 \mathrm{~mm})$ of water were used to evaluate the maximum rice yield in optimum application of water level. The highest yield 3.61 Ton /ha were observed in $3 \mathrm{~mm}$ depth of water application (Fig.10). 


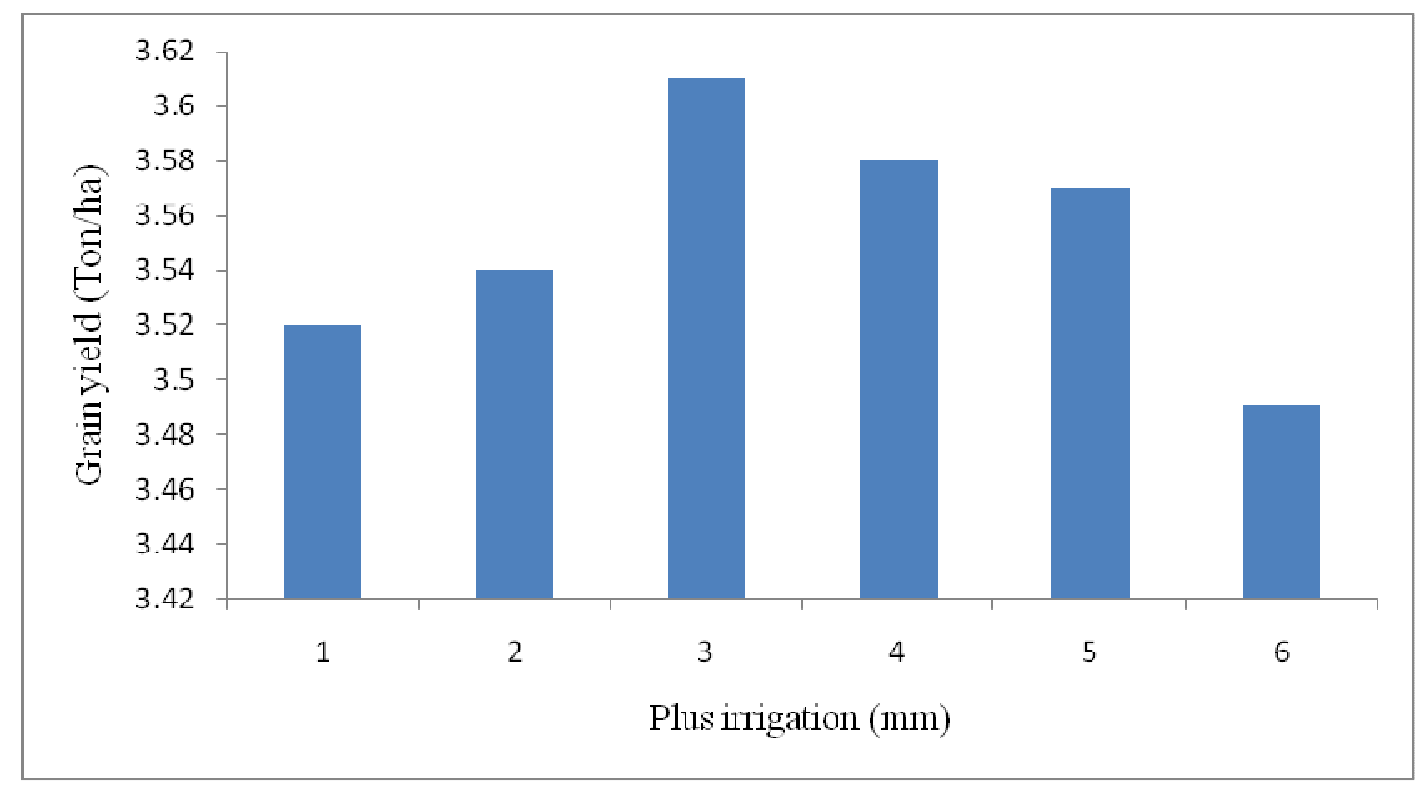

Fig. 10: Rice yield in different application rate of water.

Irrigation (water) was applied in different level $(\mathrm{mm})$ and rice yield were compared with actual yield of rice. Every water application rates $(\mathrm{mm})$ showed the positive impact except $6 \mathrm{~mm}$ depth of water application. Maximum positive impact in rice yield was $0.1 \mathrm{Ton} / \mathrm{ha}$ with the water application rate of $3 \mathrm{~mm}$ depth and negative impact in rice yield was $0.02 \mathrm{Ton} / \mathrm{ha}$ with the water application rate of $6 \mathrm{~mm}$ depth.

\section{Conclusions}

Climate change is global concern and its effect is primarily increasing in global temperature. Every sector is affected by the climate change and mostly the agricultural sector. Following conclusions are drawn from the study carried out.

- Trend analysis of 20 years data shows the maximum temperature in increasing trend while minimum temperature, rainfall and solar radiations remained almost constant during the study period.

- Increasing in minimum temperature is more risky than increasing in maximum temperature for obtaining high rice yield.

- Highest rice yield 3.66 Ton/ha, 3.8 Ton/ha, 4.039 Ton/ha and 3.61 Ton/ha were found when adjustments were made in planting date (20 July), plant density (160 plants $\left./ \mathrm{m}^{2}\right)$, nitrogen $(140 \mathrm{~kg} / \mathrm{ha})$, and application of water $(3 \mathrm{~mm})$ respectively.

- Impact of solar radiation in rice yield was found to be positive.

- Decrease in rice yield was not only the cause of climate change but also the effects of improper management. 
- In future, adaptation measures must be taken to increase or to keep constant yield of paddy (crops) by the farmers and decision makers with the help of appropriate simulating models.

\section{REFERENCES}

[1] Agarwal A., Forecasting rice yield under climate change scenarios and evaluation of agro-adaptation measures for Mekong basin region: a simulation study, 2008.

[2] Alam J., Impact assessment of climate change on maize crop in subtropical Region 2009.

[3] Bhujel R. B., Pathic D. S., Prasai H. K., Shakya P. S., Effect of organic and inorganic manure on soil and grain Yyield of normal rice at Tarahara, 2009.

[4] Chaudhary A., A long term fertility test on Munsuli rice in Nepal Agriculture Research Council, Tarahara Nepal, 1999.

[5] FAO, Agriculture 21, International Rice Commission, $<$ http://www.fao.org/ag/AGP/AGPC/doc/field/commrice/welcome.html>10 August 2007.

[6] FAO, Adaptation to climate change in agriculture, forestry and fisheries: Perspective, framework and priorities, Interdepartmental working group on climate change, Food and Agriculture Organization of the United Nations, Italy, 2007.

[7] IPCC, Climate Change 2007, Mitigation of Climate Change Contribution of Working Group III to the Fourth Assessment Report of the Intergovernmental Panel on Climate Change, Cambridge University Press, Cambridge, 2007b.

[8] IPCC, Climate Change 2007: The Physical Science Basis. Contribution of Working Group I to the Fourth Assessment Report of the Intergovernmental Panel on Climate Change, Cambridge University Press, Cambridge, 2007c.

[9] Krishnan P., Swain D. K., Bhaskar B. C., Nayak S. K., Dash R. N., Impact of elevated $\mathrm{CO} 2$ and temperature on rice yield and methods of adaptation as evaluated by crop simulation studies, Agric. Ecosyst. Environ., doi:10.1016/j.agee, 2007.

[10] Moomaw J. C. and Vergara B. S., The environment of tropical rice production 1965.

[11] International Rice Research Institute, The mineral nutrition of the rice plant. Proceedings of a Symposium at the International Rice Research Institute, The Johns Hopkins Press, Baltimore, Maryland, February, 1964.

[12] Ritchie J. T., Singh U., Godwin D. C., Bowen W. T., Cereal growth, development and yield, G.Y.Tsuji et al., (eds): Understanding Options for Agricultural Production, Kulwer Academic Publishers, Great Britain, 1998. 
[13] Rutger J. N. and Peterson M. L., Cold tolerance of rice in California, International Rice, 1979.

[14] Research Institute, Report of a rice cold tolerance workshop. Los Baños, Philippines.

[15] Statistical data book Nepal, Government of Nepal, National Planning Commission Secretariat, Central Bureau of Statistics, 2007.

[16] Wassmann R., International Rice Research Institute (IRRI), Coping with climate change, Rice Today, July-September, 2007. 